Rabong \& Rössl (2020)

\title{
ANSERJ
}

Vol. 11, No. 2

Autumn / Automne 2020

pp. $97-108$

Canadian Journal of Nonprofit and Social Economy Research

Revue canadienne de recherche sur les OBSL et l'économie sociale

\section{The Hybridization of Credit Co-Operatives in the Tradition of F.W. Raiffeisen: The Austrian Example}

\author{
Gregor Rabong \& Dietmar Rössl \\ University of Economics and Business (WU), Vienna
}

\begin{abstract}
The legal purpose of credit co-operatives in Germany and Austria is to promote their members economically. However, legal restrictions prevent them from discriminating between members and non-members. Thus, they have difficulty generating economic benefits for their members. There are signs that they are gradually developing from being purely member-focused to somewhat third party-focused co-operatives striving for the common good. The question arises whether this hybridization is in the interest of their members. This article examines this question using quantitative data. The results indicate that members perceive activities geared toward the common good as enhancing their membership value and are applicable to credit co-operatives and credit unions that have difficulties providing economic benefits to their members, as is the case for Raiffeisen credit co-operatives in Europe.
\end{abstract}

\section{RÉSUMÉ}

Le but légal des coopératives de crédit en Allemagne et en Autriche est d'aider leurs membres d'un point de vue économique. Cependant, certaines contraintes légales empêchent celles-ci de faire la distinction entre membres et nonmembres. En conséquence, elles peuvent avoir de la difficulté à réaliser des bénéfices économiques pour leurs membres. II y a toutefois des signes que, d'organismes purement focalisés sur leurs membres, elles sont en train de devenir des organismes focalisés sur des tiers et servant le bien commun. On peut se demander si une telle hybridation est dans l'intérêt des membres. Cet article examine la question en recourant à des données quantitatives. Les résultats indiquent que les membres perçoivent les activités visant le bien commun comme améliorant la valeur de leur adhésion; ils croient en outre que de telles activités sont pertinentes pour les coopératives de crédit et les caisses d'épargne là où celles-ci ont de la difficulté à fournir des bénéfices économiques à leurs membres, comme c'est le cas pour les coopératives de crédit Raiffeisen en Europe.

Keywords / Mots clés : Credit co-operatives; Membership value; Member-focused co-operative; Third party-focused co-operative; Corporate social responsibility / Coopérative focalisée sur les membres; Coopérative focalisée sur les tiers; Responsabilité sociétale des entreprises 


\section{Rabong \& Rössl (2020)}

\section{INTRODUCTION}

Friedrich Wilhelm Raiffeisen—one of the founding fathers of the co-operative movement-emphasized the local embeddedness of co-operatives (Schmale \& Blome-Drees, 2014), which should lead to a close relationship between a co-operative and its members and ensures that co-operatives are oriented toward the needs of its members (Wychera, 1985). With this, Raiffeisen emphasized not only the regional anchoring of co-operatives but also their role as regional actors beyond their direct business purpose. The demand for co-operatives to consider local specifics and developments is also reflected in one of the principles of the International Co-operative Alliance (ICA, 2019).

In spite of these ties to regionality, the primary purpose of co-operatives in many European countries, including Germany and Austria, was to support the economic benefits of their members, ${ }^{1}$ until the Societas Cooperativa Europaea (SCE; engl. European Cooperative Society) was put into effect through national laws in 2006. With the establishment of the SCE, co-operatives in Austria have also been allowed to serve social purposes. ${ }^{2}$ Yet, this development had no impact on the previously defined statutes and the self-conception of credit co-operatives. Therefore, credit co-operatives in the tradition of Raiffeisen in Europe perceive themselves as exclusively part of the "for-profit economy," which differentiates them from their counterparts in other countries. ${ }^{3}$ One example is Canada, where the Desjardins-group, which was founded by Alphonse and Dorimène Desjardins, is the leading financial co-operative. Correspondingly, this co-operative group states that:

social responsibility goes hand in hand with our mission and co-operative values. It's an integral part of our strategic plan that helps us enrich the lives of people and their communities, create value and drive performance for our members and clients. (Desjardins Group, 2018, p. 3)

According to this statement, the Canadian Desjardins Group primarily focuses on an indirect membership value. Since providing economic benefits for their members is hardly possible, Austrian credit co-operatives-similar to the Desjardins Group-are also engaged in fostering the common good. Nevertheless, Austrian credit co-operatives perceive themselves as part of the for-profit economy and market themselves in the same way as any other investor-owned bank.

Since the primary purpose of credit co-operatives is the economic promotion of their members, this presents a dilemma: they should deliver economic benefits, but due to legal restrictions (e.g., equal treatment obligation, the concealed distribution of profits), the positive discrimination between members and non-member clients is very difficult to achieve. Furthermore, market forces and fierce competition prohibit such attempts. The value proposition of a company, however, consists not only of the technical value proposition, "which puts a primary focus on the physical products and services" (Byrne \& McCarthy, 2014, p. 567), but also relational and emotional value propositions. Since members are the owners of their co-operatives, they can decide not to pursue economic benefits as their main goal but to give priority to other objectives (Mayo, 2011).

Given this situation, Austrian credit co-operatives increasingly attempt to create a "meta-economic" member benefit through socially responsible practices with a regional focus. Corporate social responsibility (CSR) can be seen as an extended corporate governance model; "whereby, who runs a firm ... has responsibilities that range from fulfillment of their fiduciary duties toward the owners, to fulfillment of analogous fiduciary duties toward all of the firm's stakeholders" (Sacconi, 2006, p. 262). CSR measures are actions put in place by a company based on its perceived societal obligations to meet the expectations of stakeholders (Schwarz, 2006). This ranges from self-restriction on input factors (e.g., no products are used that may have been produced using child labour), or self-restriction on order acceptance (e.g., no projects that adversely affect the regional economy are financed), to the support of activities that are not directly related to their own business model (e.g., when a credit co-operative actively supports the establishment of a regional car-sharing service). Today, society's expectation of companies to act responsibly and to "give something back to community" is in- 


\section{Rabong \& Rössl (2020)}

creasing, since national governments with increasing budgetary constraints are less and less capable of attending to people's needs. The efforts put forth by companies to meet public expectations in this respect have undoubtedly increased since the turn of the millennium. Statements such as: "The larger and more influential companies become, the more energetically one expects them to also show conscience" (Bartsch, 2015, n.p.) can be read as a matter of course.

In view of the statutory obligation of credit co-operatives to promote their members economically, the question has to be asked whether these CSR measures indeed increase membership value, because they actually reduce membership value in the short term due to their associated costs (Schwarz, 2005). CSR measures are only legitimized if this question can be answered in the affirmative. When credit co-operatives increasingly set CSR measures, they start to drift into the "not-for-profit economy": a mixture of "for-profit" and "not-for-profit orientation" aiming at the common good takes place, which is labelled "hybridization" (Battilana, Lee, Walker, \& Dorsey, 2012; Florin \& Schmidt, 2011; Hervieux, Fallu, \& Turcotte, 2016).

In the past, the dichotomous and partially conflicting relationship that develops between the economic performance of a co-operative and its other goals have only been discussed to a limited extent. While authors such as Lauermann, Moreira, Souza, and Ribeiro Piccoli (2018) partially elaborated on the relationship between a co-operatives economic performance and its member benefits, an answer to whether co-operatives' CSR measures are perceived as value-enhancing or valuereducing remains to be discovered. This is especially true since the differing interests of members may lead to a situation where values of one kind might be created at the expense of others (van Dijk, Sergaki, \& Baourakis, 2019).

When socially responsible behaviour in general—and with a regional focus in particular-is perceived as value enhancing, it must be proven that members feel represented by the behaviour of their co-operative. If this turns out to be the case, members subjectively attain a higher membership value, despite the associated costs. "Membership value" in this sense is described as the perceived value of being a member in the co-operative, as assessed by the member (Byrne \& McCarthy, 2014; Theurl, 2013). Since the direct beneficiaries of CSR measures (e.g., a local theatre group receiving support) are not members by design, the question arises if and how membership value can be derived when those measures do not constitute a business relationship between the co-operative and its members.

This article explores two research questions:

Research question 1: Do members of credit co-operatives perceive the CSR measures of their co-operative as a separate component of the membership value, and to what extent does this component contribute to the subjectively perceived membership value?

Research question 2: How does the proposed value stemming from CSR measures lead to a change in the basic orientation of credit co-operatives from an organizational-theoretical point of view?

These research questions can be reformulated into hypotheses:

Hypothesis 1: In spite of the primary objective of credit co-operatives to economically promote their members, they set CSR measures that are perceived by their members as contributing to their membership value.

Hypothesis 2: In principle, credit co-operatives in the tradition of Raiffeisen belong to the for-profit sector. Due to their increasing CSR-engagement, they, to some extent, pick up the logic of third party-focused co-operatives that belong to the not-for-profit sector. Thus, credit co-operatives are anchored in two worlds at the same time; hybridization takes place.

These questions will be pursued based on a marketing-theory line of argument, and further elaborated on through a quantitative study carried out at three credit co-operatives in Austria. 


\section{THE TARGET-GROUP RELATED HYBRIDIZATION OF (CREDIT) CO-OPERATIVES}

If it is assumed that CSR measures-especially CSR measures with a local focus can increase the membership value of a co-operative, the question arises as to how this could be justified within the co-operative organizational framework.

Co-operatives are fundamentally member-oriented: they act in the interest of their members, provide services to their members, and are steered by their members. Thus, they display a structure as shown in Figure 1.

Figure 1: The business model of member-focused co-operatives (Rössl, 2017)

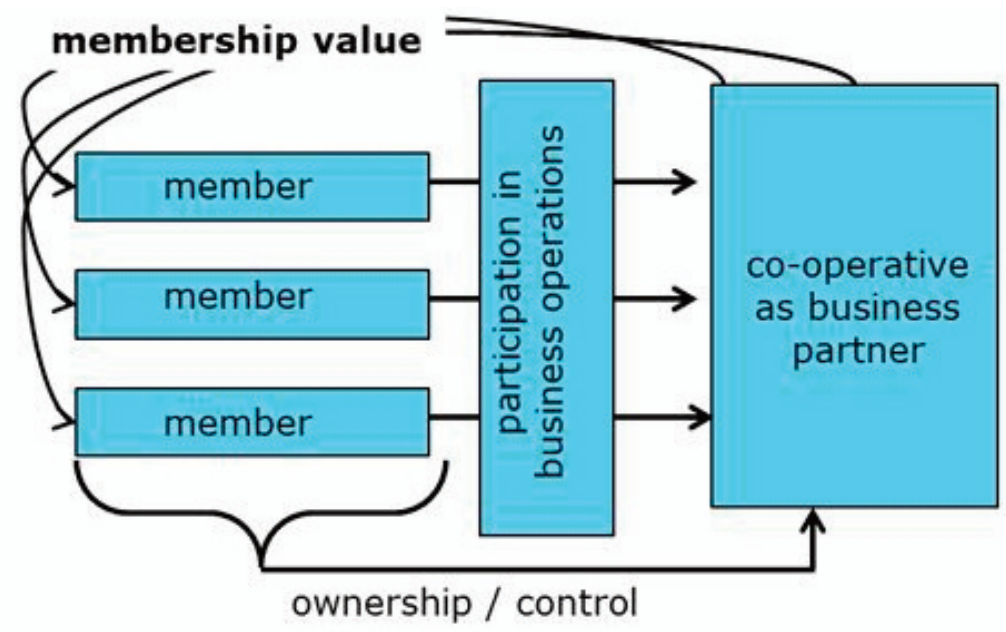

In addition to member-focused co-operatives, there are also social co-operatives, which mainly aim their services at third parties (Borzaga \& Tortia, 2006; Degli Antoni \& Portale, 2014; Engelhardt, 1983). Accordingly, these co-operatives are usually called "third-party-focused co-operatives" (Hatak, Lang and Rössl, 2016, p. 1221). In a co-operative of this kind, members are only service addressees if they belong to the defined circle of supported addressees. For example, if a cooperative supports a folklore group a member is promoted only if he/she is part of this folklore group. Another example are persons who are regarded as economically and/or socially weak from a socio-political point of view which receive financial aid by the co-operative (Schmale, 2017). When founding a social co-operative, often very diverse people come together, and most of them do not act for their personal benefit (Göler von Ravensburg, 2013). This creates an organizational form as shown in Figure 2, where the promotion of members and a direct economic membership value are not apparent at first glance.

Figure 2: The business model of third party-focused co-operatives (Rössl, 2017)

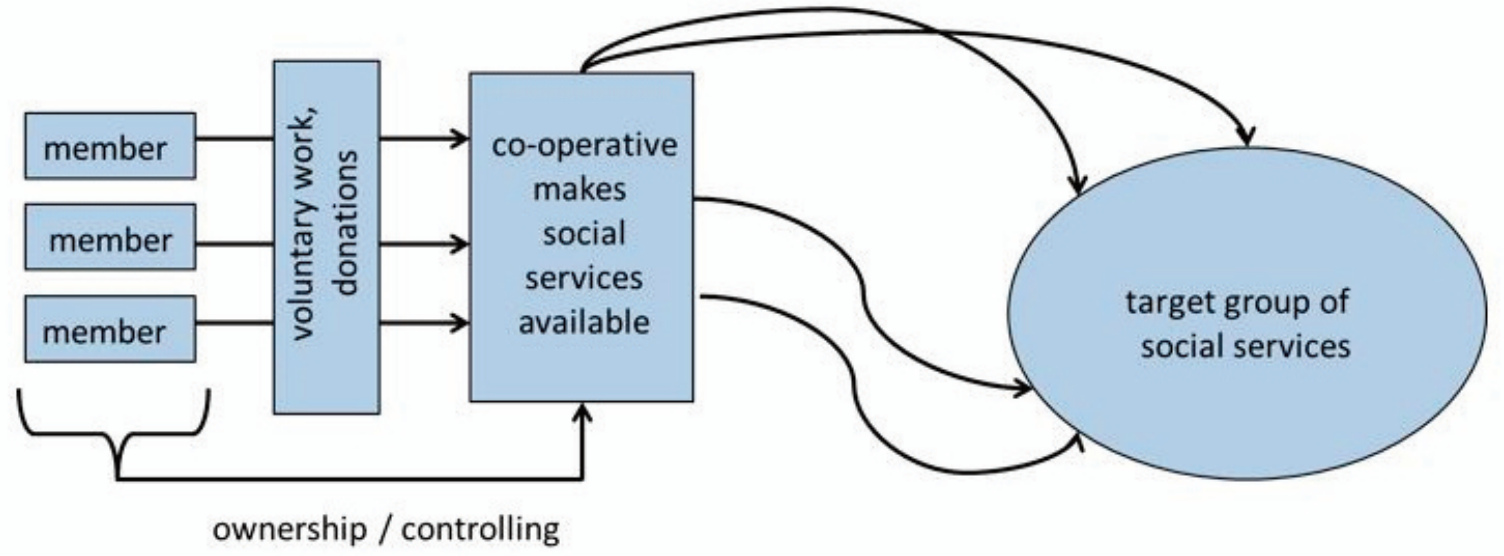


While member-focused co-operatives clearly provide membership value in their business models, the question of why members should participate in third party-focused co-operatives arises. However, third party-focused co-operatives create membership value through their societal activities (see Figure 3). Members are supported by the services of the co-operative, because they are promoted in their social concerns (SCE, 2003). Thus, third party-focused co-operatives also act in the interest of their members. After all, it is in their interest that the services reach the intended third parties.

Figure 3: Membership value in third party-focused co-operatives (Rössl, 2017)

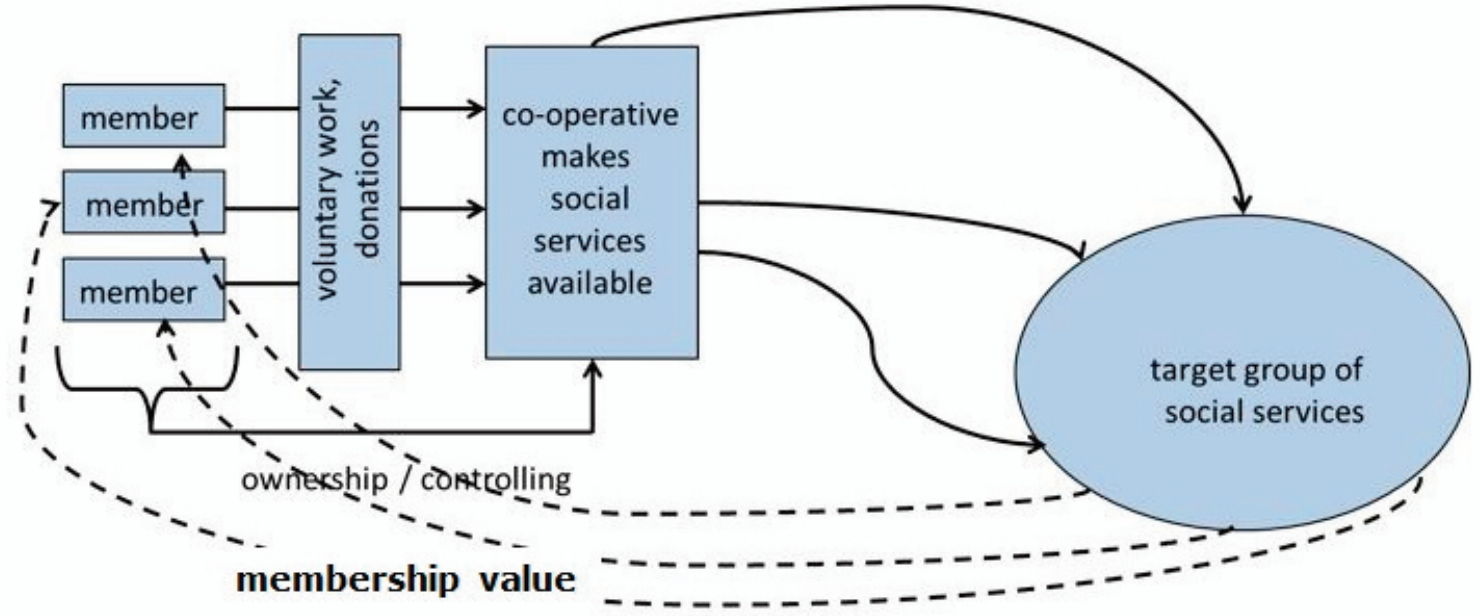

If these considerations are transferred to CSR measures of a member-focused co-operative that primarily pursues market-oriented purposes, it can be argued that the CSR actions of such a co-operative have to be legitimized to improve the membership value, because otherwise these measures fail to meet the predefined goals stipulated by law or by the statutes of the co-operative. Hence, it must be verified that the perceived membership value is increased through these actions, because the social activities and concerns of the members are promoted. In such a case, as presented in Figure 4, "membership value l" would result from participation in business operations, while "membership value II" would arise if members appreciate that their co-operative is a responsible actor in the region (Bhattacharya \& Sen, 2003). Theoretically speaking, a hybridization between a member-focused co-operative and a third party-focused co-operative is the result.

Figure 4: The hybridization of credit co-operatives (Rössl, 2017)

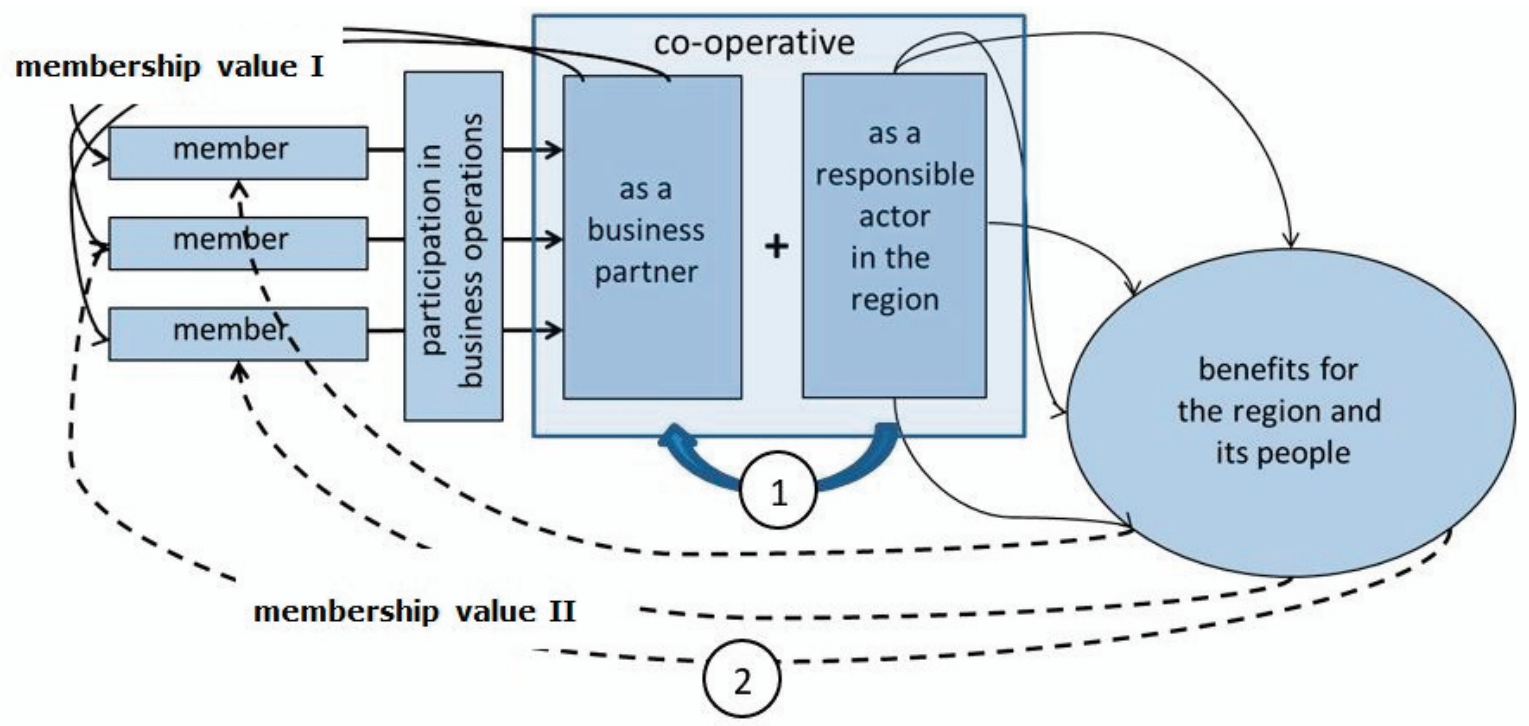


Rabong \& Rössl (2020)

\section{CSR AS A VALUE-ADDING COMPONENT OF CREDIT CO-OPERATIVES' SERVICE PORTFOLIO}

Compared to other companies, co-operatives find it easier to achieve consistency between their business objectives and social responsibility because social responsibility is already implicitly linked to the legal form of the co-operative (Giallonardo \& Mulino, 2012; ICA, 2019; Roth, 2005; Schwarz, 2006; Theurl, 2010). Hence, member-focused co-operatives might find it easier than other companies to justify CSR measures and to create a value for a customer by fostering CSR efforts.

For credit co-operatives, the principle of member promotion presupposes that there would be significant differences between banking products for members and for non-members. However, due to the legal framework (i.e., equity capital restrictions), globalization, and technological progress (leading to increased competition and the cheap supply of banking services online), credit co-operatives can hardly provide a "membership value I" (see Figure 4), which raises the question of whether a "membership value II" (see Figure 4) can be generated via CSR activities. If so, CSR efforts might (partially) counterbalance a credit co-operatives' inability to promote its members in an economic sense.

It can be argued that credit co-operatives, similar to any other company, must behave in a socially responsible manner to maintain market success, since market success is the prerequisite for the production of corresponding member success (Roth, 2005; Schwarz, 2006). Thus, if a commitment to social responsibility is positively assessed and the loyalty of customers and employees to the credit co-operative increase accordingly, CSR measures can be viewed as increasing the membership value I (see arrow number one in Figure 4) (by, for example, achieving higher reimbursements, achieving better future expectations, offering member-exclusive services, etc.) (Willersinn, Lavèn, \& Doluschitz, 2015).

The CSR activities of co-operatives are also legitimized if the members, in their role as owners, ask their co-operative to behave in a socially responsible way (Roth 2005). This is the case if the members perceive the social commitment of the co-operative as a promotion of their social concerns and consequently welcome CSR measures to increase the membership value (see arrow number two in Figure 4).

Public pressure on companies to behave in a socially responsible manner continues to increase where businesses outgrow national governments, which fortifies the connection between the economic success of a company and its societal performance. It is this environment where corporate social responsibility becomes important in market economies that have primarily been interested in maximizing profits and shareholder wealth for the past decades. From this standpoint, responsible business behaviour has become a prerequisite to gaining and maintaining a customer base.

\section{The value of CSR from a marketing point of view}

Non-co-operative companies often try to establish and cultivate relationships with their customers through customer clubs, which often mimic a co-operative membership. Through this form of membership, a long-term, more intensive relationship with customers is established (Ringle, 2005). However, it has been shown that these customer clubs often involve high costs, yet the actual returns remain relatively unclear. Furthermore, while customers feel "bound" to the company by the economic advantages of the customer club, they are not "emotionally connected" (Ringle, 2005, p. 38).

In contrast, it has been shown that customers are generally willing to commit themselves emotionally to companies if those companies radiate an authentic "value aura" that is compatible with the customers' individual value profiles (Rössl, 2012). Here, those customers who feel emotionally connected to the company constitute its community. A graphic illustration of this self-assessed assignment to a company (e.g., a credit co-operative) is presented in Figure 5. Only those customers who can (emotionally) subscribe to the values of the business will attach themselves to a company. Customers who do not agree with the value aura will not engage in a business relationship with it. 
Figure 5: The emotional linkage between customer and company (adapted from Rössl, 2017).

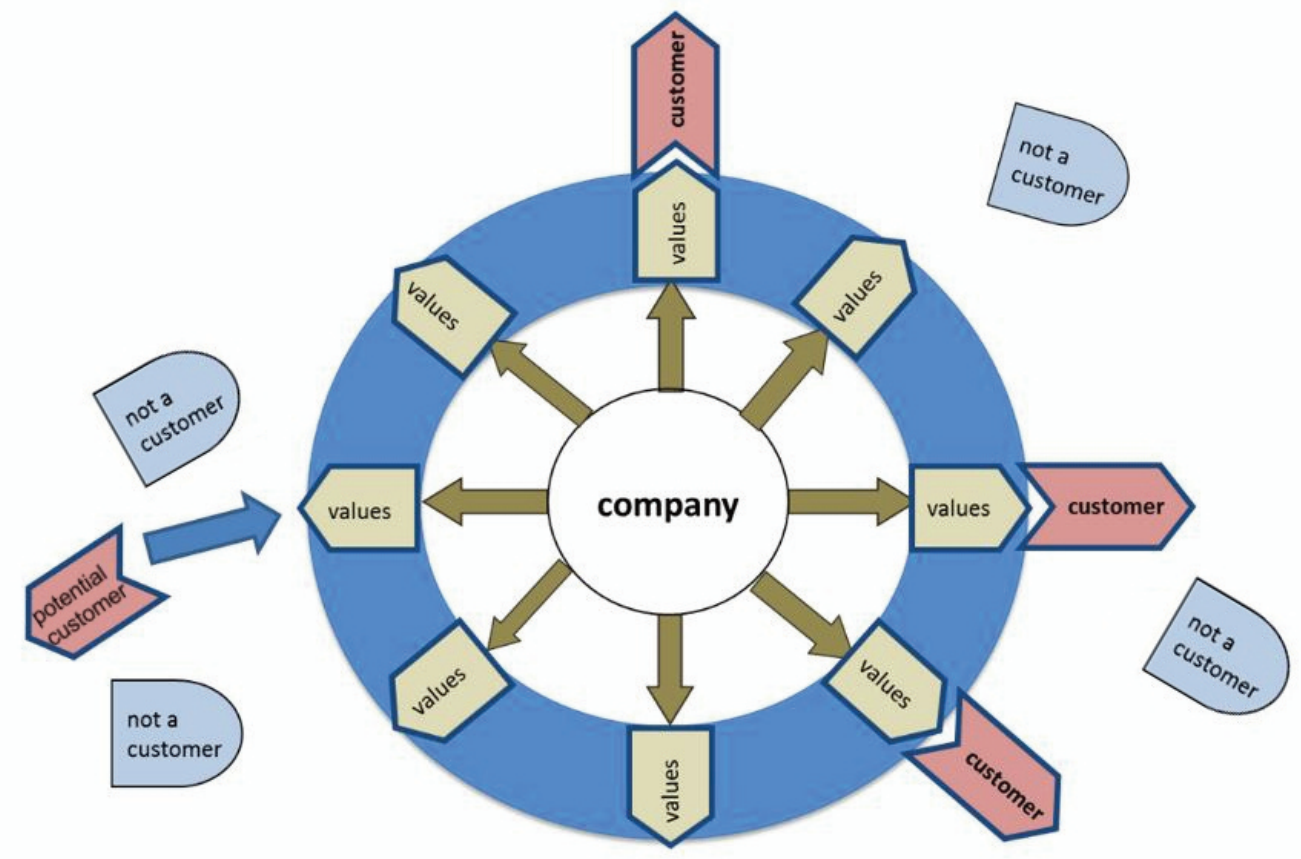

Note: Customers who do not agree with the value aura are depicted by shapes that do not fit to the values of the company.

Why should people feel emotionally connected to a company?

- Customers want "sense for money." This means a purchase should make sense beyond its core benefit, beyond its value for money (e.g., fair-trade products or "green banking"). The purchase decision is not just about the price and the product itself. The question of whether one can buy the product "in good conscience" is increasingly influential in the purchase-decision-making process of an increasing number of customers. The socially responsible actions of a company represent a competitive advantage in such situations (Fombrun \& Van Riel, 1997; Schwaiger, 2004). The larger the customer group that is looking for "sense for money," the more strongly companies are inclined to act in a socially responsible manner. Purchase decisions are made not only on the basis of economic calculations but also because of identification with the values of the company (a good feeling for money) (Carbonaro, 2006).

- Along the lines of Ferdinand Tönnies (2010), people experience too much "society" and too little "community," and therefore potential customers retrieve value from a community experience that is established around products and/or companies. Being locally anchored, companies such as credit co-operatives can therefore create a strengthened membership connection through a shared value set (Roth, 2006).

Nevertheless, it is important to remember that today's customers are marketing-savvy-they realize when a value aura was created on the drawing board. However, if companies possess an authentically perceptible value aura and have consistently displayed corresponding behaviour over many years, then this value aura can be the basis on which a customer identifies with the company and develops a stable emotional connection.

Co-operatives should be capable of creating such a value aura through and around their history that is demonstrated by their behaviour as socially responsible actors in the region. An empirical analysis will explore whether this theoretical finding also holds in reality. 
How membership value creates a regional commitment from an empirical perspective Within an exploratory research project in 2016, a stratified sample of 3,271 customers was drawn from a credit co-operative: 772 members and 2,499 non-member customers of a credit co-operative operating in an urban region.

In 2019, another stratified sample of 4,670 customers was drawn: 2,520 members and 2,150 non-member customers of two Raiffeisen Banks in rural areas were asked to complete a questionnaire. From this sample, 278 usable questionnaires were returned (191 member customers, 87 non-member customers).

There have been various attempts to break down the member-value proposition of co-operatives into partial benefits (Bhattacharya \& Sen, 2004; Byrne \& McCarthy, 2014; Mazzarol, Clark, Reboud, \& Limnios, 2018; Weidmann, 1996). According to the literature, the membership value is composed of five components (Beuthien, Hanrath, \& Weber, 2008; Fischer, 2009; Grosskopf, 1990; Ringle, 2006):

- direct economic benefits via better and/or cheaper banking products,

- benefits from the return on investment,

- ideational benefits from socially responsible business behaviour,

- benefits from additional services that lead to indirect economic benefits, and

- ideational benefits from the opportunity to have a say in the co-operative.

These components were operationalized and surveyed in the questionnaires by multiple items. In the 2019 surveys, the component "ideational benefits from CSR measures" was supplemented by "ideational benefits from the co-operative being a good corporate citizen in the region." The item that led to the formation of "economic benefits from investment" had to be eliminated to comply with the agreed-upon terms of the survey. An explorative factor analysis was conducted in order to confirm the components suggested in the literature.

When these components are ranked according to their importance for the members of the credit co-operatives (see Table 1), it is no surprise that "value for money" takes precedence. However, the partial benefit "ideational benefits from socially responsible action" is ranked higher than "advantages from additional services," which refers to club-like advantages.

Table 1: The components of membership value and their relative importance for members

\begin{tabular}{|l|c|c|}
\hline partial benefits & $\begin{array}{c}\text { important or very important for members } \\
\text { (2 coops in rural areas - survey 2019) }\end{array}$ & $\begin{array}{c}\text { important or very important for members } \\
\text { (coop in urban area - survey 2016) }\end{array}$ \\
\hline $\begin{array}{l}\text { economic advantages from banking business } \\
\text { (value for money) }\end{array}$ & $90 \%$ & $85 \%$ \\
\hline $\begin{array}{l}\text { economic benefits from investment } \\
\text { (value for money) }\end{array}$ & - & $85 \%$ \\
\hline $\begin{array}{l}\text { ideational benefits from "regionality" - being close } \\
\text { to the people (sense for money) }\end{array}$ & $95 \%$ & - \\
\hline $\begin{array}{l}\text { ideational benefits from CSR-measures } \\
\text { (sense for money) }\end{array}$ & $80 \%$ & $55 \%$ \\
\hline $\begin{array}{l}\text { benefits from additional services/customer club-like } \\
\text { services (value for money) }\end{array}$ & $40 \%$ & $55 \%$ \\
\hline $\begin{array}{l}\text { ideal benefits from co-determination } \\
\text { (sense for money) }\end{array}$ & $30 \%$ & $15 \%$ \\
\hline
\end{tabular}




\section{Rabong \& Rössl (2020)}

Therefore, it can be stated that members do indeed receive benefits from the socially responsible behaviour of their credit co-operatives (e.g., "My credit co-operative did this, and therefore I feel good as a member"). "The co-operative can act as a representative for its members who ... want to engage in society but who ... are not in a position to do so" (Roth, 2005 , p. 23). Such services are perceived by the members as a value-adding component of membership. This means that credit co-operatives, which are credible as socially responsible actors, create membership value for the members of the co-operative. The results of the survey clearly show the competitive advantage resulting from socially responsible action at a regional level.

Table 2 illustrates this competitive advantage. It is important to almost all members that companies take responsibility for the region. An overwhelming majority of members attach this characteristic to their credit co-operative. Conversely, far fewer concede that any other company is also taking responsibility for the region and the people living there.

Table 2: The credibility and visibility of the regional CSR commitment

\begin{tabular}{|l|c|c|}
\hline & $\begin{array}{c}\text { members } \\
\text { (2 coops in rural areas } \\
\text { - survey 2019) }\end{array}$ & $\begin{array}{c}\text { members } \\
\text { (coop in urban area } \\
\text { - survey 2016) }\end{array}$ \\
\hline $\begin{array}{l}\text { How important is it that companies take } \\
\text { responsibility for the region? }\end{array}$ & $\begin{array}{c}96 \% \\
\text { very important/important }\end{array}$ & $\begin{array}{c}92 \% \\
\text { very important/important }\end{array}$ \\
\hline $\begin{array}{l}\text { Does your credit co-operative take responsibility for } \\
\text { the region and the people who live in it? }\end{array}$ & $\begin{array}{c}96 \% \\
85 \% \\
\text { yes/mostly yes }\end{array}$ & $\begin{array}{l}35 \% \\
\text { yes }\end{array}$ \\
\hline $\begin{array}{l}\text { Does any other company in the region take } \\
\text { responsibility for the region and the people } \\
\text { who live in it? }\end{array}$ & $\begin{array}{l}50 \% \\
\text { yes }\end{array}$ & \multicolumn{2}{|c|}{} \\
\hline
\end{tabular}

\section{CONCLUSION}

This article aimed to uncover whether members of credit co-operatives in the tradition of Raiffeisen perceive CSR measures as value-enhancing components of their co-operatives. This question arises because credit co-operatives have difficulty providing pure economic benefits to their members. If co-operatives can supply emotional benefits via CSR measures and become an important and responsible player in the region, however, it can compensate for the negligible economic benefits. Hence, when credit co-operatives depart from the primary aim of creating economic benefits for their members and turn into organizations that also aim at providing benefits for third parties, hybridization takes place. From a theoretical point of view, it is clear that there are not just member-focused or third party-focused co-operatives but all various forms in between these two typical forms.

"In this situation, co-operatives are said to be degenerating, in that their mission evolves from member-centricity to being co-operative-centric. In other words, rather than putting the interests of its members first, the co-operative's main goal is to keep existing and growing by developing its own activities (its own business model)" (Roux \& Plé, 2017, p. 17). Building on this argument, one can conclude that Austrian credit co-operatives use CSR measures to position themselves as responsible players. They do this in order to be able to provide (meta-economic) benefits to their members, and also to ensure their own economic success.

From a marketing point of view, this might represent a competitive advantage in today's market economies. The empirical analysis shows that the value aura of credit co-operatives could indeed be the basis for members' emotional attachment to "their" responsible co-operative. It is very likely that non-members who perceive these values also develop a loyalty- 


\section{Rabong \& Rössl (2020)}

based relation to the credit co-operative. A practical conclusion that can be derived is that credit co-operatives in the tradition of Raiffeisen are well-advised to accept this hybridization as a necessary development.

When co-operatives behave as socially responsible actors in the region, benefits to the members are created that, despite the associated costs, increase the perceived value of membership. Accordingly, in their own interest (Roux \& Plé, 2017) and in the interest of their members, Austrian credit co-operatives indeed move from pure member-focused co-operatives to partially third party-focused co-operatives. Thus, hybridization can be observed. Nevertheless, Austrian credit co-operatives continue to label themselves as for-profit-organizations, denying any linkages with the social economy. ${ }^{4}$ This discrepancy may also hold true for other credit co-operatives in countries where the positive discrimination of members vis-à-vis non-members is prohibited and/or economically non-realizable.

The design of the current study is subject to some limitations. The primary limitation is that the study relies exclusively on data gathered from three Austrian credit co-operatives. As quite heterogeneous co-operatives have been selected for this study, there are good reasons to assume that the results apply to all Austrian credit co-operatives in the tradition of Raiffeisen. Nevertheless, additional co-operatives have to be studied in order to test the scope of these results. Despite the likelihood that these findings also hold true for credit co-operatives in other countries, such as the Desjardins Group in Canada, the positive impact of CSR measures on the membership value in other countries remains to be empirically confirmed. Replication studies in other countries with a strong co-operative tradition (e.g., Italy, Germany, or Canada) are desirable to check the generalizability of the results.

\section{NOTES}

1. Austrian co-operative law states that "This law applies to associations ..., which primarily serve to promote the earnings or the economic activities of their members ...." (Genossenschaftsgesetz, n.d. as amended).

2. The Statute for a European Cooperative Society states that "An SCE shall have as its principal object the satisfaction of its members' needs and/or the development of their economic and social activities ...." (Societas Cooperativa Europaea, 2003).

3. The Canada Cooperatives Act states "surplus funds ... are used ... for community welfare or the propagation of cooperative enterprises ..." (Canada, 1998).

4. A2018 attempt to set up a credit co-operative within the social economy in Austria failed because it did not receive a banking license by the Austrian Financial Market Authority.

\section{REFERENCES}

Austria. Genossenschaftsgesetz (n.d.). §1(1). URL: https://www.ris.bka.gv.at/GeltendeFassung.wxe?Abfrage=Bundes normen\&Gesetzesnummer=10001680 [October 30, 2020]..

Bartsch, B. (2015). Augen auf. McK Wissen. URL: https://www.brandeins.de/corporate-publishing/mck-wissen/mck -wissen-2015/augen-auf [October 13, 2020].

Battilana, J., Lee, M., Walker, J., \& Dorsey, C. (2012). In search of the hybrid ideal. Stanford Social Innovation Review, 10(3), 51-55.

Beuthien, V., Hanrath, S., \& Weber, H.-O. (2008). Mitglieder-Fördermanagement in Genossenschaftsbanken. Göttingen, DE: Vandenhoeck \& Ruprecht.

Bhattacharya, C.B., \& Sen, S. (2003). Consumer-company identification. Journal of Marketing, 67(2), 76-88.

Bhattacharya, C.B., \& Sen, S. (2004). Doing better at doing good: When, why, and how consumers respond to corporate social initiatives. California Management Review, 47(1), 9-24.

Borzaga, C., \& Tortia, E. (2006). Worker motivations, job satisfaction, and loyalty in public and nonprofit social service. Nonprofit and Voluntary Sector Quarterly, 35(2), 225-249. 


\section{Rabong \& Rössl (2020)}

Byrne, N., \& McCarthy, O. (2014). Value proposition preferences of credit union members and patronage activity. International Journal of Bank Marketing, 32(6), 567-589.

Canada. (1998). Canada Cooperatives Act, Sect 7(1)(g)(iv). URL: https://laws-lois.justice.gc.ca/eng/acts/c-1.7/page -2.html\#h-45068 [August 10, 2020].

Carbonaro, S. (2006). Ehrlichkeit ist auch eine Strategie, Interview. brand eins, 8(4), 82-87.

Degli Antoni, G., \& Portale, E. (2011). The effect of corporate social responsibility on social capital creation in social cooperatives. Nonprofit and Voluntary Sector Quarterly, 40(3), 566-582.

Desjardins Group. (2018). Social and cooperative responsibility report. URL: https://www.desjardins.com/ressources /pdf/d50-rapport-sociale-2018-e.pdf?resVer=1553786641000 [August 10, 2020].

Engelhardt, W.W. (1983). Gemeinwirtschaftliche Genossenschaften - ein möglicher Widmungstyp von Genossenschaften unter sechsen. Journal for Public and Nonprofit Services, 6(1), 30-47.

Florin, J., \& Schmidt, E. (2011). Creating shared value in the hybrid venture area: A business model innovation perspective. Journal of Social Entrepreneurship, 2(2), 165-197.

Fischer, D. (2009). Gesamtleistungsmaximierung als Operationalisierung des kreditgenossenschaftlichen Erfolgs.

Presentation at the Nachwuchswissenschaftlertagung der Arbeitsgemeinschaft genossenschaftswissenschaftlicher Institute. Baunatal, DE.

Fombrun, C., \& Van Riel, C. (1997). The reputational landscape. Corporate Reputation Review, 1(2), 5-13.

Giallonardo, L., \& Mulino, M. (2012). Heterogeneous producers' cooperatives and corporate social responsibility.

Proceedings of the European Business Research Conference 2012. doi:10.2139/ssrn.213394

Göler von Ravensburg, N. (2013). Chancen für die eingetragene Genossenschaft in der Sozialwirtschaft. Journal for Public and Nonprofit Services, 36(2-3), 89-105.

Grosskopf, W. (1990). Strukturfragen der deutschen Genossenschaften, Teil I - Der Förderungsauftrag moderner Genossenschaftsbanken und seine Umsetzung in die Praxis. Frankfurt, DE: Veröffentlichung der DG Bank.

Hatak, I., Lang, R., Rössl, D. (2016). Trust, social capital, and the coordination of relationships between the members of cooperatives: A comparison between member-focused cooperatives and third-party-focused cooperatives, Voluntas: International Journal of Voluntary and Nonprofit Organizations 27(3), 1218-1241.

Hervieux, C., Fallu, J.-M., \& Turcotte, M.-F. (2016). Les organisations hybrides. Canadian Journal of Nonprofit and Social Economy Research, 7(1), 5-21.

International Co-operative Alliance. (2019). Cooperative identity, values \& principles. URL: https://tinyurl.com/yyuugt5y [October 29, 2019].

Lauermann, G.J., Moreira, V.R., Souza, A., \& Ribeiro Piccoli, P.G. (2018). Do cooperatives with better economicfinancial indicators also have a better socioeconomic performance? Voluntas. doi:10.1007/s11266-018-0036-5.

Mayo, E. (2011). Co-operative performance. Sustainability Accounting, Management and Policy Journal, 2(1), $158-164$.

Mazzarol, T., Clark, D., Reboud, S., \& Limnios, E.M. (2018). Developing a conceptual framework for the co-operative and mutual enterprise business model. Journal of Management \& Organization, 24(4), 551-581.

Rössl, D. (2012). Relationship-management für KMU. Mit Beiträgen aus Wissenschaft und Praxis, 2nd. ed. Vienna, AT: Facultas.

Rössl, D. (2017). Das gesellschaftlich verantwortliche Agieren von Genossenschaften als Komponente des Membership-Value. Zeitschrift für das gesamte Genossenschaftswesen 67(2), 67-83.

Ringle, G. (2005). Management der Mitgliederbindung in Genossenschaften. Fachzeitschrift für Verbands- und Nonprofit-Management, 31(2), 38-49.

Ringle, G. (2006). Aktive Mitgliedschaft - ein strategischer Wettbewerbsvorteil der Genossenschaften. In H.-H. Münkner \& G. Ringle (Eds.), Zukunftsperspektiven für Genossenschaften (pp. 153-177). Bern, CH, Stuttgart, DE, \& Vienna, AT: Haupt.

Roth, K. (2005). Zwischen Selbstverständnis und Strategie, Corporate Citizenship in Kreditgenossenschaften. Münster, DE: Lit Verlag. 


\section{Rabong \& Rössl (2020)}

Roth, K. (2006). Gemeinwohlorientierung als business case: Corporate citizenship und dessen Potenziale für Kreditgenossenschaften. Journal for Public and Nonprofit Services, 29(3), 309-320.

Roux, B., \& Plé, L. (2017). Business cooperatives: When does sharing become a drawback? The Journal of Business Strategy, 38(4), 11-20.

Sacconi, L. (2006). A social contract account for CSR as extended model of corporate governance. Journal of Business Ethics, 68(3), 259-281.

Schmale, I. (2017). Sozialgenossenschaften: Eine wieder entdeckte Rechts- und Wirtschaftsform in der Sozialwirtschaft.

In J. Blome-Drees \& I. Schmale (Eds.), Genossenschaft innovativ (pp. 11-45). Wiesbaden, DE: Springer.

Schmale, I., \& Blome-Drees, J. (2014). Genossenschaften als Akteure der Regionalen Entwicklung. Sozialer

Fortschritt, 63(8), 186-190.

Schwaiger, M. (2004). Components and parameters of corporate reputation. Schmalenbach Business Review, 56(1), 46-71.

Schwarz, P. (2005). Genossenschaftsmanagement im Dilemma zwischen Profit-, Nonprofit- und

Gemeinwohlorientierung. In R. Purtschert (Ed.), Das Genossenschaftswesen in der Schweiz (pp. 193-217). Bern, $\mathrm{CH}$, Stuttgart, DE, \& Vienna, AT: Haupt.

Schwarz, P. (2006). Grossgenossenschaften: Vom Förderauftrag zur Corporate Citizenship? Zeitschrift für das gesamte Genossenschaftswesen, 56(1), 59-74.

Societas Cooperativa Europaea (SCE). (2003). Council regulation 2003/1435/EG über das Statut der Europäischen Genossenschaft, Article 1(3).

Theurl, T. (2010). Genossenschaftliche Kooperationen. In D. Ahlert \& M. Ahlert (Eds.), Handbuch Franchising und Cooperation (pp. 71-105). Frankfurt, DE: Deutscher Fachverlag GmbH.

Theurl, T. (2013). Gesellschaftliche Verantwortung von Genossenschaften durch Membervalue-Strategien. Zeitschrift für das gesamte Genossenschaftswesen, 63(2), 81-94.

Tönnies, F. (2010). Gemeinschaft und Gesellschaft. Grundbegriffe der reinen Soziologie. (Reprint of edition published in 1935; original work published 1887). Darmstadt, DE: Wissenschaftliche Buchgesellschaft.

van Dijk, G., Sergaki, P., \& Baourakis, G. (2019). The cooperative enterprise: Practical evidence for a theory of cooperative entrepreneurship. Cham, $\mathrm{CH}$ : Springer.

Weidmann, O. (1996). Genossenschaften aus Mitgliedersicht unter besonderer Berücksichtigung von Transaktionskosten. Hohenheim, DE: Forschungsstelle für Genossenschaftswesen.

Willersinn, C., Lavèn, P., \& Doluschitz, R. (2015). Möglichkeiten und Grenzen von Genossenschaften zur Erhaltung der Lebensqualität im ländlichen Raum. Zeitschrift für das gesamte Genossenschaftswesen, 65(1), 41-58.

Wychera, R. (1985). Genossenschaftsideologie und -praxis im Volksbankenverbund. In W. Kemmetmüller (Ed.), Genossenschaften - Die Kooperationsform für den Mittelstand (pp. 223-238). Vienna, AT: Orac.

\section{ABOUT THE AUTHORS/LES AUTEURS}

Gregor Rabong is Research Assistant at the Research Institute for Cooperation and Cooperatives (RiCC), University of Economics and Business (WU) Vienna. Email: gregor.rabong@wu.ac.at.

Dietmar Rössl is Head of the Research Institute for Cooperation and Cooperatives (RiCC), University of Economics and Business (WU), Vienna. Email: dietmar.roessl@wu.ac.at. 